R. M. Perrin · O. Konopatskaya $\cdot$ Y. Qiu $\cdot$ S. Harper $\cdot$

D. O. Bates · A. J. Churchill

\title{
Diabetic retinopathy is associated with a switch in splicing from anti- to pro-angiogenic isoforms of vascular endothelial growth factor
}

Received: 16 December 2004 / Accepted: 17 June 2005 / Published online: 29 September 2005

(C) Springer-Verlag 2005

\begin{abstract}
Aims/hypothesis: Proliferative diabetic retinopathy results from excess blood vessel growth into the vitreous fluid of the eye. Retinal angiogenesis is regulated by expression of vascular endothelial growth factor (VEGF), and many studies have shown that VEGF is critically involved in proliferative diabetic retinopathy. VEGF is alternatively spliced to form the angiogenic $\left(\mathrm{VEGF}_{\mathrm{xxx}}\right)$ and potentially anti-angiogenic $\left(\mathrm{VEGF}_{\mathrm{xxx}} \mathrm{b}\right)$ family of isoforms. The VEGF $_{\mathrm{xxx}} \mathrm{b}$ family is found in normal tissues, but downregulated in renal and prostate cancer. Previous studies on endogenous expression of VEGF in the eye have not distinguished between the two families of isoforms. Methods: We measured $\mathrm{VEGF}_{\mathrm{xxx}} \mathrm{b}$ isoform expression in normal human eye tissue (lens, sclera, retina and iris) and vitreous fluid using enzyme-linked immunosorbent assay and Western blotting with a VEGF $\mathrm{Vxx}_{\mathrm{x}} \mathrm{b}$-specific antibody. Results: VEGF $_{\mathrm{xxx}} \mathrm{b}$ protein was expressed in lens, sclera, retina, iris and vitreous fluid. Multiple isoforms

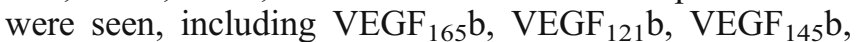
$\mathrm{VEGF}_{183} \mathrm{~b}$ and $\mathrm{VEGF}_{189} \mathrm{~b}$. In non-diabetic patients, $64 \pm 7 \%$ of the VEGF in the vitreous was $\mathrm{VEGF}_{\mathrm{xxx}} \mathrm{b}(n=18)$, whereas in diabetic patients only $12.5 \pm 3.6 \%$ of total VEGF was $\mathrm{VEGF}_{\mathrm{xxx}} \mathrm{b}$. Conclusions/interpretation: Since $\mathrm{VEGF}_{\mathrm{xxx}} \mathrm{b}$ inhibits $\mathrm{VEGF}_{\mathrm{xxx}}$-induced angiogenesis in a one-to-one stoichiometric manner, these results show that in the eye of diabetic patients VEGF splicing was switched from an antiangiogenic to a pro-angiogenic environment. This occurred through changes to the ratio of $\mathrm{VEGF}_{\mathrm{xxx}}$ : $\mathrm{VEGF}_{\mathrm{xxx}} \mathrm{b}$.
\end{abstract}

Konopatskaya and Perrin are joint first authors.

R. M. Perrin · O. Konopatskaya · Y. Qiu · S. Harper ·

D. O. Bates $(\triangle)$

Department of Physiology, Preclinical Veterinary School,

Microvascular Research Laboratories, University of Bristol,

Southwell Street,

Bristol, BS2 8EJ, UK

e-mail: Dave.Bates@bris.ac.uk

Tel.: +44-117-9289818

Fax: +44-117-9288151

A. J. Churchill

Department of Ophthalmology, Bristol Eye Hospital,

Bristol, UK
Alterations to splicing, and through that to the balance of VEGF isoforms, could therefore be a potential therapeutic strategy for diabetic retinopathy.

Keywords Angiogenesis - Proliferative diabetic retinopathy $\cdot$ Splicing $\cdot$ VEGF $\cdot V E_{121} \mathrm{~b} \cdot \mathrm{VEGF}_{165} \mathrm{~b}$

Abbreviations GAPDH: glyceraldehyde-3-phosphate dehydrogenase gene - VEGF: vascular endothelial growth factor - VEGF $\mathrm{xxx}_{\mathrm{x}}$ : angiogenic isoform of VEGF . $\mathrm{VEGF}_{\mathrm{xxx}} \mathrm{b}$ : anti-angiogenic isoform of VEGF

\section{Introduction}

Diabetic retinopathy is the leading cause of blindness in the working population of the Western world and one of the most prominent pathological complications of diabetes. In the early stages the dominant features are microaneurysms, small haemorrhages and leakage of lipids into the retina. With time this progresses to capillary closure, retinal hypoxia and more extensive exudation from retinal vessels. Advanced retinopathy is reached when excessive capillary closure has led to abnormal proliferation of retinal vessels, accompanied by vitreous haemorrhage and fibrosis [1]. The development of retinal neovascularisation is obligatorily dependent on hypoxia-induced production of vascular growth factors, and this is thought to be a major contributor to diabetic retinal neovascularisation and proliferative retinopathy [2]. This hypoxia-driven angiogenesis is a complex process mediated by factors from the vascular endothelial growth factor (VEGF), angiopoietin and ephrin families. Angiogenesis underlies many other disease states, including cancer, rheumatoid arthritis and psoriasis [3]. New therapies that influence new vessel formation are effective in animals and have entered clinical trials in retinopathy as well as in cancer and heart disease. VEGF (also referred to as VEGF-A) is the dominant pro-angiogenic factor in diabetic retinopathy, stimulating endothelial cell proliferation, migration and increased microvascular permeability and blood flow by activation of its cognate 
receptors VEGF-receptor 1 (FLT1) and VEGF-R2 (KDR/ FLK1) [3].

VEGF has been shown to be significantly up-regulated in diabetic retinopathy, particularly in retinal pigmented epithelial cells, glial cells and vitreal fibroblasts [4]. Furthermore, there is mounting functional evidence that inhibition of angiogenesis, both non-specifically with pharmacological anti-angiogenic agents and specifically with anti-VEGF agents, ameliorates neovascularisation in well-characterised animal models of retinopathy [5]. Subtle mutations in the $5^{\prime}$ region of the $V E G F$ gene can predispose to diabetic retinopathy, suggesting that regulation of transcription or splicing of the $V E G F$ gene is important in this condition [6]. Recent clinical trials of agents that inhibit VEGF have been shown to have some effectiveness in choroidal neovascularisation cause by age-related macular degeneration [7] and in animal models of retinal neovascularisation [5].

The mRNA encoding VEGF is differentially spliced from eight exons to encode at least six different proteins (Fig. 1). These proteins are termed, according to the number of amino acids, $\mathrm{VEGF}_{121}, \mathrm{VEGF}_{165}$ (the dominant isoform), $\mathrm{VEGF}_{189}$, etc. A recently described family of isoforms of VEGF, termed $V_{E G F} \mathrm{bx}$ [8], is formed by distal splice site selection in exon 8 , resulting in an mRNA containing 18 bases coded for by exon $8 \mathrm{~b}$, in place of the 18 bases of exon $8 \mathrm{a}$. This alternative splicing results in an alternative family of VEGF isoforms [9], which produce proteins of the same length as other forms, but with a different $\mathrm{C}$-terminal amino acid sequence. This family has been termed $\mathrm{VEGF}_{\mathrm{xxx}} \mathrm{b}$, where ${ }_{x x x}$ is the number of amino acids encoded. Interestingly, the receptor-binding domains and dimerisation domains are intact in these new isoforms.

The first member of this family to be identified was $\mathrm{VEGF}_{165} \mathrm{~b}$, and this is the only isoform which has been characterised in terms of its actions on endothelial cells. The receptor-binding domains are still present in $\mathrm{VEGF}_{165} \mathrm{~b}$; it binds to the receptor but does not stimulate angiogenesis signalling. Furthermore, it inhibits the proliferative, migratory and vasodilator effects of VEGF 165 and, unlike the $\mathrm{VEGF}_{\mathrm{xxx}}$ family of isoforms, $\mathrm{VEGF}_{\mathrm{xxx}} \mathrm{b}$ is down-regulated in both renal cell carcinoma and malignant prostate tissue $[8$, 9]. Neither $V_{E G F}$ xxx expression in the eye, nor relative expression of the pro-versus anti-angiogenic isoforms in the diabetic eye have been investigated previously.

\section{Materials and methods}

Materials

All materials were provided by Sigma, unless otherwise specified. The $\mathrm{VEGF}_{165} \mathrm{~b}$ antibody was generated in house

a
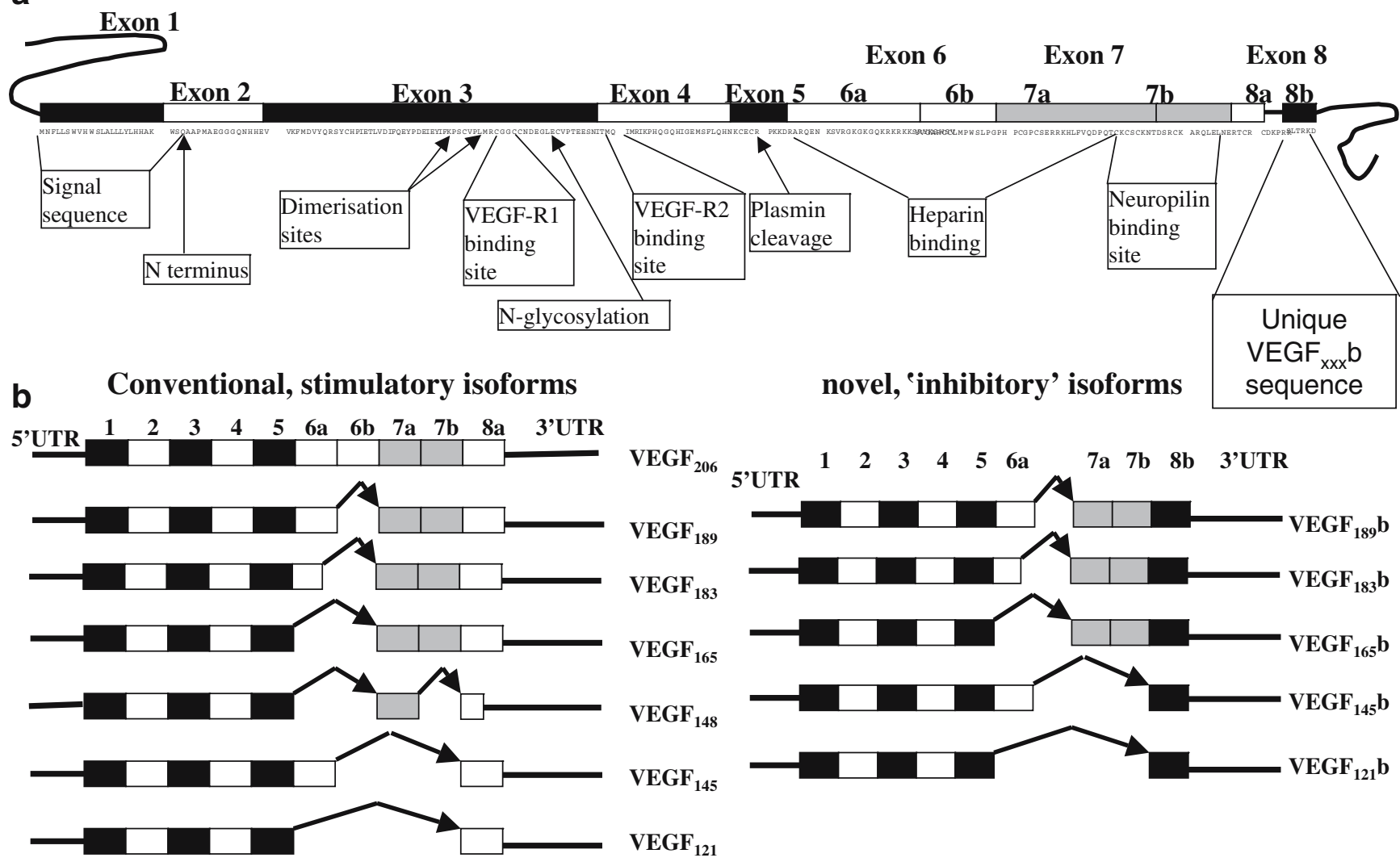

Fig. 1 Diagram showing the splicing of $V E G F$. a Structure of the $V E G F$ gene. Differential splicing into and out of exons 6, 7 and 8 produces alternative splice forms. $\mathbf{b}$ Two families of splice variants have been identified, the conventional isoforms, splicing into the

start of exon 8 (exon $8 \mathrm{a}$ ), and a sister family of potentially inhibitory isoforms, which splice distally into exon 8 to result in translation of an alternative $\mathrm{C}$-terminal six amino acids. This sequence, SLTRKD was used to generate the VEGF $\mathrm{xxx}_{\mathrm{x}}$ b-specific antibody used here 
as previously described [9] (clone 56/1), and is available from the corresponding author. The VEGF antibodies for Western blotting were from Santa Cruz Biotechnology (VEGF-A20 antibody; Santa Cruz, CA, USA). Capture antibody for ELISA, $\mathrm{VEGF}_{165} \mathrm{~b}$ protein, $\mathrm{VEGF}_{165}$ protein and the Duoset VEGF ELISA detection kit were provided by R\&D Systems (Minneapolis, MN, USA).

\section{Patient samples}

Vitreous fluid was collected from 13 diabetic patients undergoing vitrectomy for complicated proliferative retinopathy. Three of these had type 1 , the remainder type 2 diabetes. Control vitreous samples were taken from 18 patients without diabetes and with normal blood glucose, who were undergoing vitrectomy for various conditions, including retinal detachment and macular hole surgery. Human eye tissue was obtained from corneal graft donors within $48 \mathrm{~h}$ of death. All human tissue was collected with informed consent and local ethics committee approval.

\section{Measurement of total VEGF and $\mathrm{VEGF}_{\mathrm{xxx}} \mathrm{b}$}

Total VEGF concentrations in vitreous fluid were measured using a standard VEGF ELISA (Duoset). VEGF $_{\mathrm{xxx}} \mathrm{b}$ was measured with a similar capture ELISA, using the same capture antibody as in the pan-VEGF ELISA, but with a mouse monoclonal detection antibody raised in house against the terminal nine amino acids of $V_{E G F} 165$, and a standard curve using recombinant human $\mathrm{VEGF}_{165} \mathrm{~b}$ as described by Woolard and colleagues [9]. A biotinylated secondary goat anti-mouse $\operatorname{IgG}$ was used to detect the VEGF $_{165}$ b antibody. To determine the concentration of protein in the vitreous, the concentration in the vitrectomy specimens was calculated assuming a total eye volume of $4 \mathrm{ml}$. Concentrations of $\mathrm{VEGF}_{\mathrm{xxx}}$ were calculated by subtracting $\mathrm{VEGF}_{\mathrm{xxx}} \mathrm{b}$ from total VEGF.

\section{Western blotting}

Western blotting of membranes containing 12-15 $\mu \mathrm{g}$ of protein extracted from microdissected human eye tissues was carried out as previously described [9]. Blots were probed only once, with either a pan-VEGF antibody or the $\mathrm{VEGF}_{165} \mathrm{~b}$ antibody. Figures are representative blots from tissue taken from six donors, and probed separately.

\section{RT-PCR}

Vitreous fluid was collected from consenting individuals undergoing surgery at Bristol Eye Hospital. These samples were kept on ice and RNA was extracted as soon as possible. The vitreous fluid was transferred to $50 \mathrm{ml}$ Falcon tubes and spun at $2500 \mathrm{~g}$ (RC-3B; Sorvall, Stevenage, UK) for $10 \mathrm{~min}$ at $4^{\circ} \mathrm{C}$, and the pellet was retained for RNA extraction. Each pellet was homogenised in $750 \mu \mathrm{l}$ Trizol reagent and mRNA extracted according to the manufacturers' instructions. Five per cent mRNA was reverse transcribed using poly $d(T)$ as a primer and Expand RT (Roche, Indianapolis, IN, USA). This was then amplified by PCR using intron-spanning primers specific for $V_{E G F} 165$, which specifically detect $\mathrm{VEGF}_{165} \mathrm{~b}$, even in the presence of a 50 -fold greater concentration of $\operatorname{VEGF}_{165}[10]$. The primers were: antisense primer 5'-TCA GTC TTT CCT GGT GAG AGA TCT GCA-3', sense primer 5'- TTG TAC AAG ATC CGC AGA CG -3'. The gene for glyceraldehyde-3-phosphate dehydrogenase $(G A P D H)$, which was used as a housekeeping gene, was amplified from each sample using sense primer $5^{\prime}$-GTC TTC ACC ACC ATG GAG-3' and antisense primer 5'-ACC TTG CCC ACA GCC TTG GC-3'. cDNA was amplified using $1 \mu \mathrm{mol} / 1$ of each primer (20 pmol), $1.5 \mathrm{mmol} / 1 \mathrm{MgCl}_{2}$, $200 \mathrm{mmol} / \mathrm{l} \mathrm{dNTPs}$, and 2 units of Taq polymerase (AbGene, Epsom, Surrey, UK). Reactions were cycled 35 times (denaturing at $94^{\circ} \mathrm{C}$ for $30 \mathrm{~s}$, annealing at $63^{\circ} \mathrm{C}$ for $30 \mathrm{~s}$ and extending at $72^{\circ} \mathrm{C}$ for $60 \mathrm{~s}$ ). Products were analysed on a $3 \%$ agarose gel with $0.5 \mathrm{~g} / \mathrm{ml}$ ethidium bromide. For semiquantitation, the gels were scanned into Adobe Photoshop using an Agfa scanner; the intensity of the band was measured with Image $\mathrm{J}$ (NIH, Bethesda, MD, USA) and normalised to the intensity of the GAPDH band.

\section{Results}

$\mathrm{VEGF}_{\mathrm{xxx}} \mathrm{b}$ isoforms are expressed in normal human eye tissue

Western blots probed with a VEGF antibody that recognises all isoforms (pan-VEGF antibody) detected multiple bands corresponding to monomers and dimers of $\mathrm{VEGF}_{121}$, VEGF $_{189}$ and VEGF $_{165}$. In some tissues, bands were also seen at molecular weights corresponding to the long-VEGF isoforms previously described as being formed by alternative start codon usage [11]. Interestingly, probes of the same protein sample with an antibody raised to the terminal nine amino acids of the $\mathrm{VEGF}_{\mathrm{xxx}} \mathrm{b}$ family (specific for the sequence RTCSLTRKD) showed many of the same bands as the pan-VEGF antibody. In particular, monomers corresponding to $\mathrm{VEGF}_{121} \mathrm{~b}, \mathrm{VEGF}_{165} \mathrm{~b}$ and $\mathrm{VEGF}_{189} \mathrm{~b}$ were seen in iris and retina, and dimers were seen in all tissues. Another band was seen more strongly in retina, corresponding to $\mathrm{VEGF}_{145} \mathrm{~b}$ (asterisk in Fig. 2). This band was weaker, but still clearly observed in other eye tissues (Fig. 2). In addition, a band consistent with $\mathrm{VEGF}_{183} \mathrm{~b}$ was seen in the retina and other tissues (marked by a cross in Fig. 2). The VEGF $_{183}$ isoform has previously been shown to be expressed in the Müller cells of the eye [12], but this is the first evidence for expression of the isoform $V_{E G F}{ }_{183} b$. These results show clear expression of multiple isoforms of the VEGF $_{x x x}$ b family in the normal human eye. 
a

Anti-VEGF

(all isoforms, both families) b

Anti-VEGF ${ }_{x x x} b$

(C-terminus-specific)

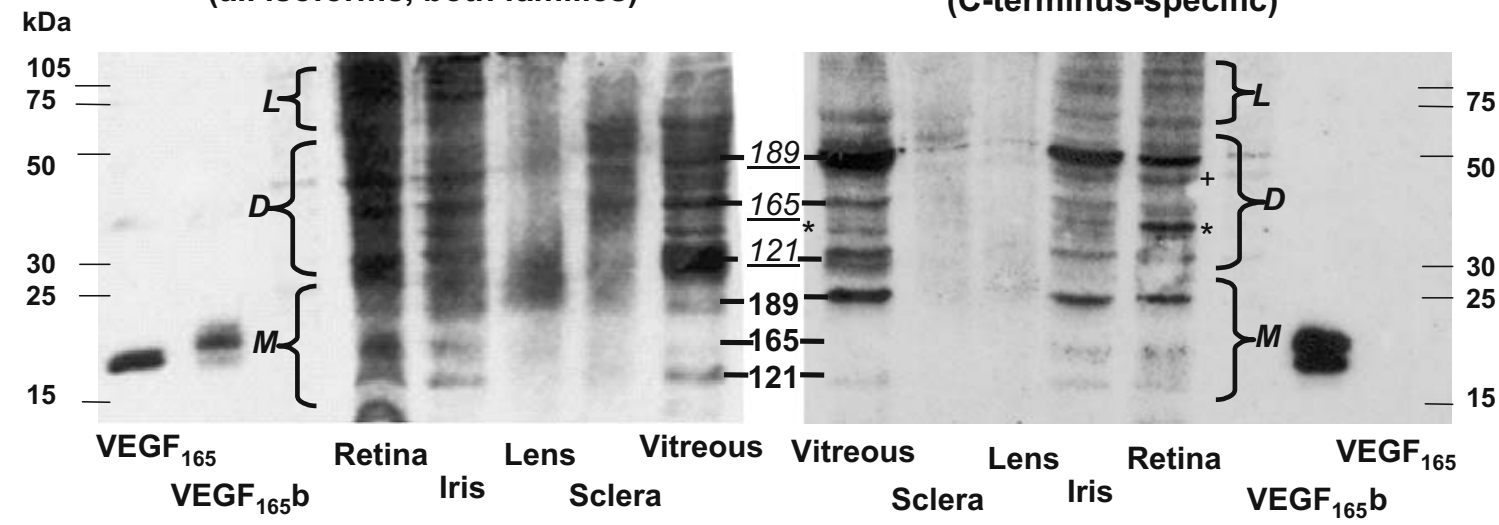

Fig. $2 V$ VGF $_{x x x} b$ expression in human eye tissue. Human eyes were dissected and protein was extracted. a Western blotting of the protein using antibody to all VEGF isoforms showed multiple bands, but corresponding to known VEGF isoforms. b Probes of a similar membrane with an antibody specific for the unique C-terminus of $\mathrm{VEGF}_{\mathrm{xxx}} \mathrm{b}$ showed multiple bands corresponding to

VEGF $_{x x x} b$ mRNA isoforms are more detectable in normal than in diabetic vitreal cells

To determine whether vitreal cells expressed $\mathrm{VEGF}_{\mathrm{xxx}} \mathrm{b}$ isoforms, mRNA was extracted from pelleted cells from the vitreous and reverse-transcribed. PCR was then performed using exon $8 \mathrm{~b}$-specific primers. Bands corresponding to $\mathrm{VEGF}_{\mathrm{xxx}} \mathrm{b}$ isoforms $\left(\mathrm{VEGF}_{165} \mathrm{~b}, \mathrm{VEGF}_{189} \mathrm{~b}\right.$, etc.) were those shown in (a); specifically, $\operatorname{VEGF}_{121} \mathrm{~b}, \mathrm{VEGF}_{165} \mathrm{~b}$ and VEGF $_{189}$ b were clearly seen in vitreous from normal subjects. In the retina a band consistent with $\mathrm{VEGF}_{145} \mathrm{~b}(*)$ was highly expressed compared with $\mathrm{VEGF}_{121} \mathrm{~b}$, and $\mathrm{VEGF}_{183} \mathrm{~b}$ also appeared to be expressed in retina $(+)$, whereas in the vitreous $\mathrm{VEGF}_{121} \mathrm{~b}$ was more highly expressed than $\operatorname{VEGF}_{145} \mathrm{~b}$
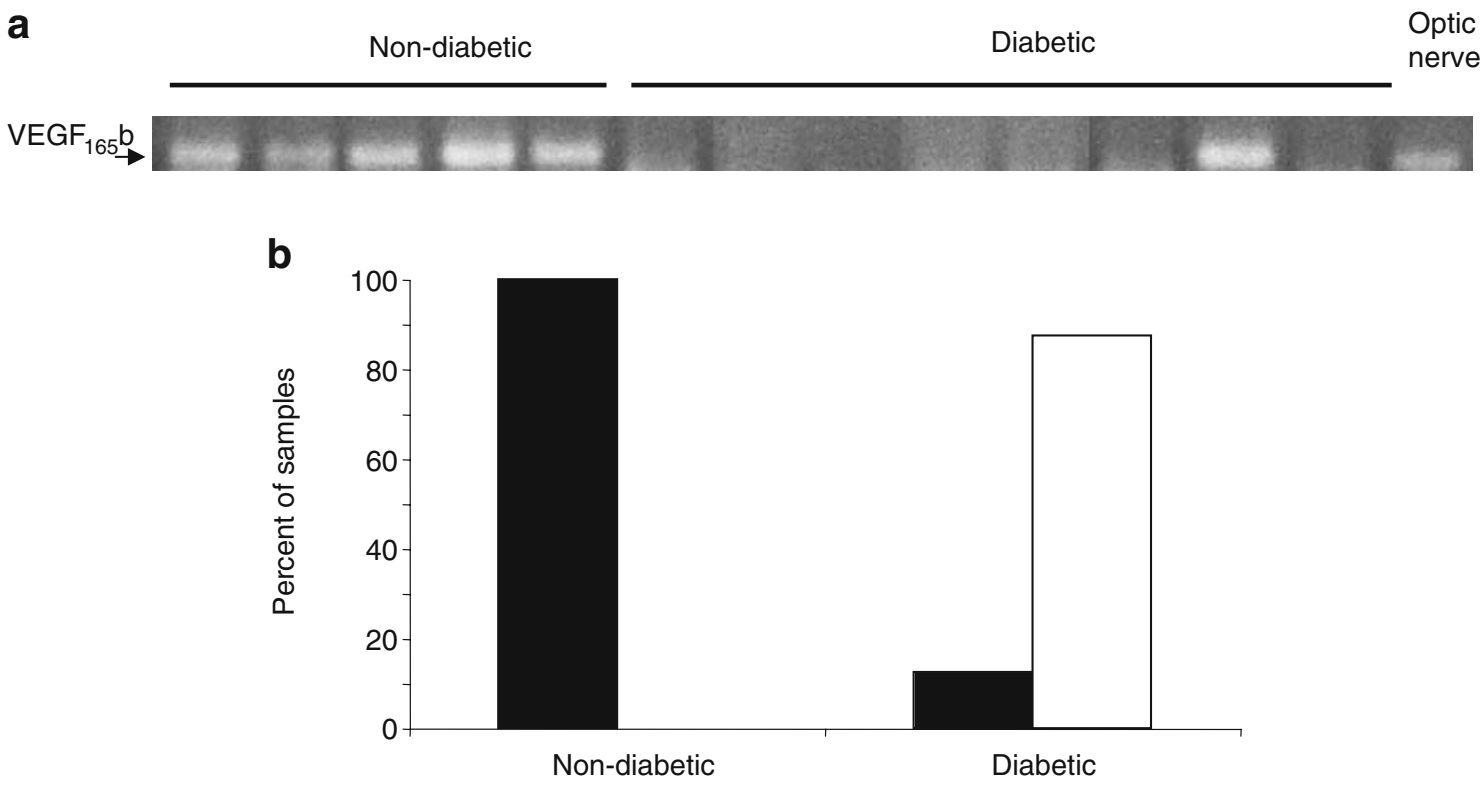

Fig. 3 VEGF $_{x x x} b$ mRNA in vitrectomy specimens. mRNA extracted from pelleted cells in the vitreous was reverse-transcribed and PCR performed using exon 8b-specific primers. Bands (a) corresponding to $\mathrm{VEGF}_{\mathrm{xxx}} \mathrm{b}$ isoforms $\left(\mathrm{VEGF}_{165} \mathrm{~b}, \mathrm{VEGF}_{189} \mathrm{~b}\right.$ etc.) were seen in all five control samples but in only one of eight diabetic samples. This seen in all five control samples but in only one of eight diabetic samples (Fig. 3). This PCR protocol did not amplify VEGF 165 CDNA, but did amplify a band from mRNA extracted from optic nerve. The mean intensity of the bands was significantly greater in the non-diabetic $(124 \pm 13.5 \%$ compared with $G A P D H$ ) than in the diabetic vitreal mRNA (54 $\pm 18.6 \%$ compared with $G A P D H ; p<0.05$, Mann-Whitney $U$ test).

PCR protocol did not amplify VEGF $_{165}$ cDNA, but did amplify a band of mRNA extracted from optic nerve. b Percentage of samples expressing (closed bars) or not expressing (open bars) $\mathrm{VEGF}_{\mathrm{xxx}} \mathrm{b}$ mRNA. $p<0.01$, Fisher's exact test 
a

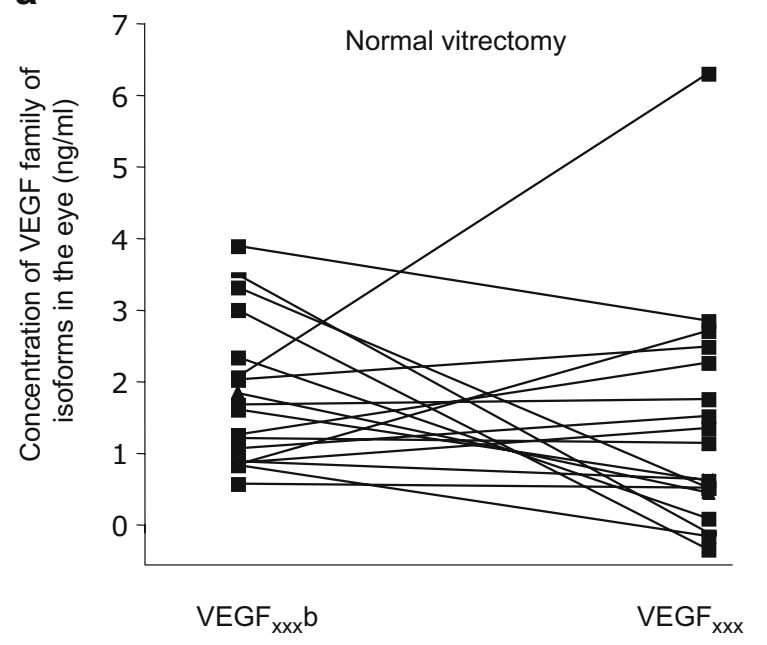

b

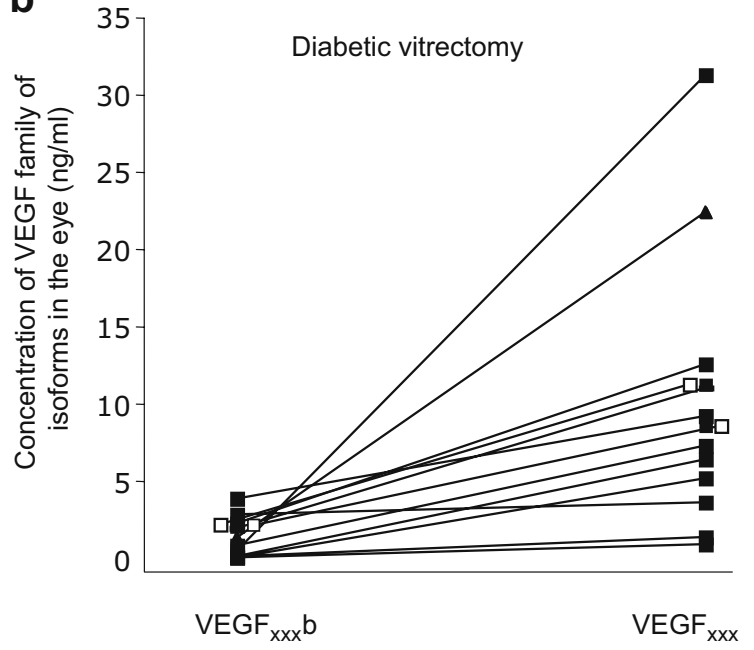

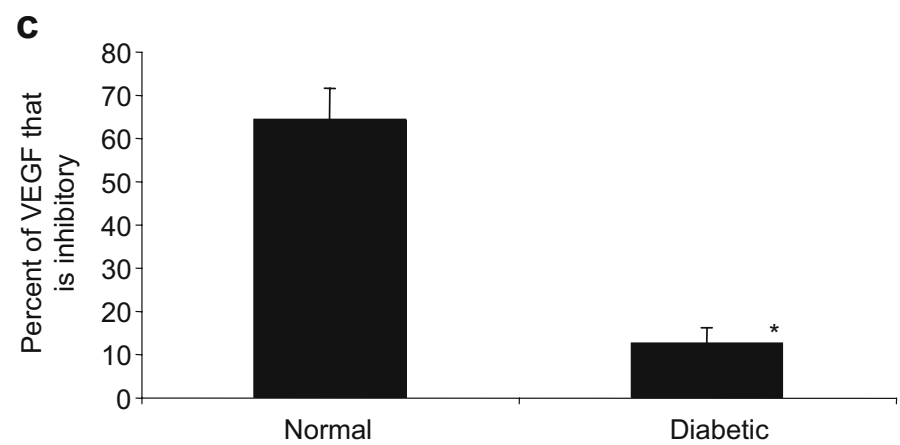

Fig. $4 \operatorname{VEGF}_{\mathrm{xxx}} \mathrm{b}$ and $\mathrm{VEGF}_{\mathrm{xxx}}$ concentrations in normal and diabetic vitreous. a The levels of expression of these two families of splice variant were similar in normal vitreous. $\mathbf{b} \mathrm{VEGF}_{\mathrm{xxx}}$ isoforms were expressed at a significantly higher level than $\mathrm{VEGF}_{\mathrm{xxx}} \mathrm{b}$ in diabetic vitreous. Open squares, type 1 diabetes; closed squares, type 2 diabetes. $\mathbf{c}$ The percentage of total VEGF in the vitreous that

$\mathrm{VEGF}_{\mathrm{xxx}} \mathrm{b}$ isoforms are the predominant isoform in normal but not in diabetic vitreous

To determine whether diabetic retinopathy resulted in an alteration in the balance of isoforms, ELISAs were carried out to measure the concentrations of $\mathrm{VEGF}_{\mathrm{xxx}} \mathrm{b}$ and total VEGF in normal and diabetic vitreous fluid. Figure $4 \mathrm{a}$ shows that in normal vitreous the concentrations of $\mathrm{VEGF}_{\mathrm{xxx}}$ (mean \pm SEM, $1.36 \pm 0.38 \mathrm{ng} / \mathrm{ml})$ and $\operatorname{VEGF}_{\mathrm{xxx}} \mathrm{b}(1.81 \pm$ $0.24 \mathrm{ng} / \mathrm{ml}$ ) are comparable ( $p>0.1$, paired $t$-test). In diabetic vitreous, however, the concentration of $\operatorname{VEGF}_{\mathrm{xxx}}(10.0 \pm$ $2.3 \mathrm{ng} / \mathrm{ml}$ ) is significantly greater than that of $\mathrm{VEGF}_{\mathrm{xxx}} \mathrm{b}$ $(1.34 \pm 0.34 ; p<0.001$, paired $t$-test; Fig. $4 \mathrm{~b})$. In fact, in the normal vitreous $\mathrm{VEGF}_{\mathrm{xxx}} \mathrm{b}$ isoforms account for nearly twothirds of the total VEGF $(65.3 \pm 7.2 \%)$, which is significantly higher than the $12.5 \pm 3.6 \%(p<0.001$, unpaired $t$-test $)$ found in diabetic vitreous (Fig. 4c).

\section{Discussion}

Since the first identification of increased VEGF expression in the eyes of patients with diabetes by Adamis and col- was inhibitory (i.e. $\operatorname{VEGF}_{\mathrm{xxx}} \mathrm{b}$ ) was significantly higher in the normal than in the diabetic vitreous. Angiogenesis would be completely inhibited at a $2: 1$ ratio of $\operatorname{VEGF}_{\mathrm{xxx}} \mathrm{b}(66 \%)$, whereas angiogenesis would be highly favoured when $\mathrm{VEGF}_{\mathrm{xxx}} \mathrm{b}$ expression was less than $33 \%$. ${ }^{*} p<0.001$ compared with control; unpaired $t$-test

leagues in 1994, over 500 studies have investigated VEGF in diabetic retinopathy and other diabetic conditions [13]. This is the first one to show that the eye, under normal conditions, contains endogenous, distally spliced variants of VEGF that would act to inhibit vessel growth. From the data described above, it appears that the levels of antiangiogenic VEGF are unchanged in patients with diabetic retinopathy compared with non-diabetic patients. In the former, however, pro-angiogenic VEGF levels are preferentially up-regulated and overwhelm the anti-angiogenic family of isoforms. We do not know whether this switch is due to the diabetes or to the diabetic retinopathy. This raises many interesting scenarios for treatment and necessitates re-examination of the mechanism underlying diabetic proliferative retinopathy.

The mechanisms that underlie the control of splicing of VEGF isoforms from anti- to pro-angiogenic are completely unknown. However, it appears that in diabetes the two families of isoforms are not equally affected, suggesting that the regulation of the expression of the anti-angiogenic isoforms is different for that of the pro-angiogenic isoforms. Although some $V E G F$ gene polymorphisms have been associated with diabetes, none of these have been linked to 
exon $8 \mathrm{~b}$ splicing. None of the known polymorphisms fall in either the exon $8 \mathrm{~b}$ region (presumably containing exonsplicing enhancers) or the intronic polypyrimidine tract upstream of exon $8 \mathrm{~b}$. However, regulation of splicing originating from upstream regions of the gene could result in alterations in the recruitment of splicing factors to the RNA polymerase complex and control of the speed of the polymerase reaction. It is possible, therefore, that some of the upstream polymorphisms (e.g. -460C) could affect splicing.

An understanding of the mechanism of splicing regulation may provide a method for switching off angiogenesis in the diabetic eye: if the switch can be turned off, then the increase in VEGF would be just as inhibitory as it is stimulatory for angiogenesis. Furthermore, the effects of inhibitors of VEGF on the anti-angiogenic isoforms are unknown. There have been no studies to determine whether VEGF-sequestering agents, such as VEGF-TRAP or aptamers [14] against VEGF, can affect pro- and anti-angiogenic isoforms equally. Specific inhibition of pro-angiogenic isoforms might appear to be a more effective strategy for preventing proliferation. With the recent findings that inhibition of VEGF proves an extremely effective treatment in phase III clinical trials [15] in age-related macular degeneration, it is not unreasonable to speculate that increasing the concentration of $\mathrm{VEGF}_{\mathrm{xxx}} \mathrm{b}$ isoforms to equal or surpass those of the pro-angiogenic isoforms may be an effective therapeutic strategy for inhibiting the progression of proliferative diabetic retinopathy. It is clear that the role of VEGF splicing in the regulation of angiogenesis in the eye, and in other conditions, is going to be a key factor in our understanding of the progression of diabetic eye disease.

Acknowledgements This work was supported by Diabetes UK (RD02/002520), the Wellcome Trust $(57936$, 69029), the British Heart Foundation (FS02/053 and BB2000030), the Showering Fund, the Bristol Urological Institute and the Richard Bright VEGF Research Trust.

\section{References}

1. De La Cruz JP, Gonzalez-Correa JA, Guerrero A, de la Cuesta FS (2004) Pharmacological approach to diabetic retinopathy. Diabetes Metab Res Rev 20:91-113
2. Pe'er J, Shweiki D, Itin A, Hemo I, Gnessin H, Keshet E (1995) Hypoxia-induced expression of vascular endothelial growth factor by retinal cells is a common factor in neovascularizing ocular diseases. Lab Invest 72:638-645

3. Bates DO, Harper SJ (2002) Regulation of vascular permeability by vascular endothelial growth factors. Vascul Pharmacol 39:225-237

4. Malecaze F, Clamens S, Simorre-Pinatel Vet al (1994) Detection of vascular endothelial growth factor messenger RNA and vascular endothelial growth factor-like activity in proliferative diabetic retinopathy. Arch Ophthalmol 112:1476-1482

5. Aiello LP, Pierce EA, Foley ED et al (1995) Suppression of retinal neovascularization in vivo by inhibition of vascular endothelial growth factor (VEGF) using soluble VEGF-receptor chimeric proteins. Proc Natl Acad Sci U S A 92:1045710461

6. Awata T, Inoue K, Kurihara S et al (2002) A common polymorphism in the $5^{\prime}$-untranslated region of the VEGF gene is associated with diabetic retinopathy in type 2 diabetes. Diabetes 51:1635-1639

7. Eyetech (2003) Anti-vascular endothelial growth factor therapy for subfoveal choroidal neovascularization secondary to agerelated macular degeneration: phase II study results. Ophthalmology 110:979-986

8. Bates DO, Cui TG, Doughty JM et al (2002) VEGF165b, an inhibitory splice variant of vascular endothelial growth factor, is down-regulated in renal cell carcinoma. Cancer Res 62: 4123-4131

9. Woolard J, Wang WY, Bevan HS et al (2004) VEGF165b, an inhibitory vascular endothelial growth factor splice variant: mechanism of action, in vivo effect on angiogenesis and endogenous protein expression. Cancer Res 64:7822-7835

10. Cui TG, Foster RR, Saleem M et al (2004) Differentiated human podocytes endogenously express an inhibitory isoform of vascular endothelial growth factor (VEGF165b) mRNA and protein. Am J Physiol Renal Physiol 286:F767-F773

11. Huez I, Bornes S, Bresson D, Creancier L, Prats H (2001) New vascular endothelial growth factor isoform generated by internal ribosome entry site-driven CUG translation initiation. Mol Endocrinol 15:2197-2210

12. Jingjing L, Xue Y, Agarwal N, Roque RS (1999) Human Muller cells express VEGF183, a novel spliced variant of vascular endothelial growth factor. Investig Ophthalmol Vis Sci 40:752-759

13. Adamis AP, Miller JW, Bernal MT et al (1994) Increased vascular endothelial growth factor levels in the vitreous of eyes with proliferative diabetic retinopathy. Am J Ophthalmol 118: 445-450

14. Eyetech (2002) Preclinical and phase 1A clinical evaluation of an anti-VEGF pegylated aptamer (EYE001) for the treatment of exudative age-related macular degeneration. Retina 22:143152

15. Gragoudas ES, Adamis AP, Cunningham ET Jr, Feinsod M, Guyer DR (2004) Pegaptanib for neovascular age-related macular degeneration. N Engl J Med 351:2805-2816 